\title{
PENDIDIKAN KARAKTER: SUATU KEBUTUHAN BAGI MAHASISWA DI ERA MILENIAL
}

\author{
Margi Wahono ${ }^{1}$
}

\begin{abstract}
Abstrak: Pendidikan karakter kini menjadi salahsatu wacana utama dalam kebijakan nasional di bidang karakter Pendidikan. Seluruh kegiatan belajar serta mengajar yang ada dalam negara indonesia harus merujuk pada pelaksanaan pendidikan Karakter. Ini juga termuat di dalam Naskah Rencana Aksi Nasional Pendidikan Karakter yang diterbitkan oleh Kementerian Pendidikan pada tahun 2010. Dalam naskah tersebut dinyatakan yakni pendidikan karakter menjadi unsur utama dalam pencapaian visi dan misi pembangunan Nasional yang termasuk pada RPJP 2005-2025. Bukan hanya itu dalam UU RI No 20 tahun 2003 tentang Sistem Pendidikan Nasional; merumuskan fungsi dan tujuan pendidikan Nasional yang harus digunakan dalam mengembangkan upaya pendidikan di Indonesia. Pasal 3

UU SIKDIKNAS menyebutkan: -Pendidikan Nasional berfungsi mengembangkan dan membantu watak serta peradaban bangsa yang bermartabat dalam rangka mencerdaskan bangsa. Bertujuan untuk berkembangnya potensi, peserta didik agar menjadi manusia yang beriman yang bertakwa kepada Tuhan Yang Maha Esa, berakhlak mulia, sehat, berilmu, cakap, kreatif, mandiri dan menjadi warga negara yang demokratis serta bertanggung jawabll.
\end{abstract}

\section{PENDAHULUAN}

Dalam upaya menyelamatkan lingkungan hidup, aplikasi pendidikan karakter yang dapat diterapkan yakni; 1) Membangun karakter peduli lingkungan melalui keteladanan. Membangun karakter peduli lingkungan dalam diri seseorang tidak semudah membalikkan telapak tangan. Keteladanan merupakan salah satu imbauan untuk digunakan dalam pengelolaan lingkungan sehingga terasa dampak yang muncul sangat dahsyat. Dalam dunia pendidikan sinergi antara rumah dan sekolah sangat membantu untuk membangun kepedulian lingkungan. Orang tua menjadi tempat pendidikan awal sebelum anak-anak mendapatkan pendidikan di tempat lain. Orang tua harus menanamkan kebiasaan peduli lingkungan dalam kehidupan sehari-hari. 2) Membangun karakter peduli lingkungan melalui pembiasaan. Berbagai program di sekolah bisa dijadikan program untuk membangun karakter peserta didik peduli lingkungan. Karena itu langkah-langkah pembentukan karakter bisa dilakukan semua warga sekolah dan menjadi pembiasaan. Pembiasaan yang dapat dilakukan adalah: a) Masukkan konsep karakter peduli lingkungan pada setiap kegiatan pembelajaran dengan cara: (a) Menanamkan nilai kebaikan/manfaat bagi kehidupan apabila lingkungan hidup tetap terjaga kelestariannya.

Membangun karakter peduli lingkungan di sekolah memerlukan tiga pilar. Pilar yang dipakai untuk mewujudkan sekolah berkarakter peduli lingkungan meliputi tiga hal. Pertama, membangun watak, kepribadian dan moral. Kedua, membangun kecerdasan majemuk. Ketiga, kebermaknaan pembelajaran. Agar ketiga pilar itu tetap pada landasan yang kokoh, maka 
diperlukan kontrol agar segala upaya sesuai dengan skenario yang ada. Keteladanan dan pembiasaan merupakan upaya untuk menumbuhkan dan mengembangkan karakter peduli lingkungan di sekolah dan harus menjadi pijakan menuju pengelolaan lingkungan hidup yang lebih baik. Keteladanan dan pembiasaan harus tercermin dalam program-program yang dicanangkan sekolah dan akan terlihat perwujudannya dalam sikap dan kepedulian berprilaku sehari-hari, baik di sekolah maupun di rumah. Jika ada sinergi antara sekolah dan rumah dalam membangun kepedulian terhadap lingkungan, maka anak-anak akan mampu menjadi agen perubahan lingkungan yang berkualitas di masa datang.

Lickona (1992) menjelaskan beberapa alasan perlunya pendidikan karakter, di antaranya: (1) Banyaknya generasi muda saling melukai karena lemahnya kesadaran pada nilai-nilai moral, (2) Memberikan nilai-nilai moral pada generasi muda merupakan salah satu fungsi peradaban yang paling utama, (3) Peran sekolah sebagai pendidik karakter menjadi semakin penting ketika banyak anak-anak memperoleh sedikit pengajaran moral dari orangtua, masyarakat, atau lembaga keagamaan, (4) masih adanya nilai-nilai moral yang secara universal

masih diterima seperti perhatian, kepercayaan, rasa hormat, dan tanggungjawab, (5) Demokrasi memiliki kebutuhan khusus untuk pendidikan moral karena demokrasi merupakan peraturan dari, untuk dan oleh masyarakat, (6) Tidak ada sesuatu sebagai pendidikan bebas nilai. Sekolah mengajarkan pendidikan bebas nilai. Sekolah mengajarkan nilainilai setiap hari melalui desain ataupun tanpa desain, (7) Komitmen pada pendidikan karakter penting manakala kita mau dan terus menjadi guru yang baik, dan (8) Pendidikan karakter yang efektif membuat sekolah lebih beradab, peduli pada masyarakat, dan mengacu pada performansi akademik yang meningkat.

Alasan-alasan di atas menunjukkan bahwa pendidikan karakter sangat perlu ditanamkan sedini mungkin untuk mengantisipasi persoalan di masa depan yang semakin kompleks seperti semakin rendahnya perhatian dan kepedulian anak terhadap lingkungan sekitar, tidak memiliki tanggungjawab, rendahnya kepercayaan diri, dan lain-lain.

Gerakan PPK menempatkan nilai karakter sebagai dimensi terdalam pendidikan yang membudayakan dan memberadabkan para pelaku pendidikan. Ada lima nilai utama karakter yang saling berkaitan membentuk jejaring nilai yang perlu dikembangkan sebagai prioritas Gerakan PPK (Kemdikbud). Kelima nilai utama karakter bangsa yang dimaksud adalah sebagai berikut:

\section{Religius}

Nilai karakter religius mencerminkan keberimanan terhadap Tuhan yang Maha Esa yang diwujudkan dalam perilaku melaksanakan ajaran agama dan kepercayaan yang dianut, menghargai perbedaan agama, menjunjung tinggi sikap toleran terhadap

pelaksanaan ibadah agama dan kepercayaan lain, hidup rukun dan damai dengan pemeluk agama lain. Nilai karakter religius ini meliputi tiga dimensi relasi sekaligus, yaitu hubungan individu 
dengan Tuhan, individu dengan sesama, dan individu dengan alam semesta (lingkungan). Nilai karakter religius ini ditunjukkan dalam perilaku mencintai dan menjaga keutuhan ciptaan.

Subnilai religius antara lain cinta damai, toleransi, menghargai perbedaan agama dan kepercayaan, teguh pendirian, percaya diri, kerja sama antar pemeluk agama dan kepercayaan, antibuli dan kekerasan, persahabatan, ketulusan, tidak memaksakan kehendak, mencintai lingkungan, melindungi yang kecil dan tersisih.

\section{Nasionalis}

Nilai karakter nasionalis merupakan cara berpikir, bersikap, dan berbuat yang menunjukkan kesetiaan, kepedulian, dan penghargaan yang tinggi terhadap bahasa, lingkungan fisik, sosial, budaya, ekonomi, dan politik bangsa, menempatkan kepentingan bangsa dan negara di atas kepentingan diri dan kelompoknya.

Subnilai nasionalis antara lain apresiasi budaya bangsa sendiri, menjaga kekayaan budaya bangsa,rela berkorban, unggul, dan berprestasi, cinta tanah air, menjaga lingkungan,taat hukum, disiplin, menghormati keragaman budaya, suku,dan agama.

\section{Mandiri}

Nilai karakter mandiri merupakan sikap dan perilaku tidak bergantung pada orang lain dan mempergunakan segala tenaga, pikiran, waktu untuk merealisasikan harapan, mimpi dan citacita.

Subnilai mandiri antara lain etos kerja (kerja keras), tangguh tahan banting, daya juang, profesional, kreatif, keberanian, dan menjadi pembelajar sepanjang hayat.

\section{Gotong Royong}

Nilai karakter gotong royong mencerminkan tindakan menghargai semangat kerja sama dan bahu membahu menyelesaikan persoalan bersama, menjalin komunikasi dan persahabatan, memberi bantuan/pertolongan pada orangorang yang membutuhkan.

Subnilai gotong royong antara lain menghargai, kerja sama, inklusif, komitmen atas keputusan bersama, musyawarah mufakat, tolongmenolong, solidaritas, empati, anti diskriminasi, anti kekerasan, dan sikap kerelawanan.

\section{Integritas}

Nilai karakter integritas merupakan nilai yang mendasari perilaku yang didasarkan pada upaya menjadikan dirinya sebagai orang yang selalu dapat dipercaya dalam perkataan, tindakan, dan pekerjaan, memiliki komitmen dan kesetiaan pada nilai-nilai kemanusiaan dan moral (integritas moral).

Kelima hal di atas akan lebih efektif apabila pihak sekolah menerapkan budaya sekolah yang secara nyata dapat menunjang pelaksanaan. Budaya sekolah yang positif akan mendorong semua warga sekolah untuk bekerjasama yang didasarkan saling percaya, mengundang partisipasi seluruh warga, mendorong munculnya gagasan-gagasan baru, dan

memberikan kesempatan untuk terlaksananya pembaharuan di sekolah yang semuanya ini bermuara pada pencapaian hasil terbaik. Budaya sekolah yang baik dapat menumbuhkan iklim yang mendorong semua warga sekolah untuk belajar, yaitu belajar bagaimana belajar 
dan belajar bersama. Akan tumbuh suatu iklim bahwa belajar adalah menyenangkan dan merupakan kebutuhan, bukan lagi keterpaksaan. Belajar yang muncul dari dorongn diri sendiri, intrinsic motivation, bukan karena tekanan dari luar dalam segala bentuknya. Akan tumbuh suatu semangat di kalangan warga sekoalah untuk senantiasa belajar tentang sesuatu yang memiliki nilai-nilai kebaikan.

Budaya sekolah yang baik dapat memperbaiki kinerja sekolah, baik kepala sekolah, guru, siswa, karyawan maupun pengguna sekolah lainnya. Situasi tersebut akan terwujud ketika kualifikasi budaya tersebut bersifat sehat, solid, kuat, positif, dan professional. Dengan demikian

suasana kekeluargaan, kolaborasi, ketahanan belajar, semangat terus maju, dorongan untuk bekerja keras dan belajar mengajar dapat diciptakan. Selanjutnya, dalam analisis tentang budaya sekolah dikemukakan bahwa untuk mewujudkan budaya sekolah yang akrab-dinamis, dan positif-aktif perlu adanya sebuah semacam rekayasa sosial. Dalam mengembangkan budaya baru, sekolah perlu diperhatikan dua level kehidupan sekolah: yaitu level individu dan level organisasi atau level sekolah, tujuannya adalah agar budaya baru yang akan diterapkan agar dapat menyatu dengan baik dengan iklim dan suasana yang ada di sekolah tersebut. Level individu, merupakan perilaku siswa selaku individu yang tidak lepas dari budaya sekolah yang ada. Perubahan budaya sekolah memerlukan perubahan perilaku individu. Perilaku individu siswa sangat terkait dengan prilaku pemimpin sekolah.
Suyitno (2012) menjelaskan bahwa karakter dapat diartikan sebagai bawaan, hati, jiwa, kepribadian, budi pekerti, perilaku, personalitas, sifat, tabiat,temperamen, dan watak. Karakter dalam pengertian ini menandai dan memfokuskan pengaplikasian nilai kebaikan dalam bentuk tindakan atau tingkah-laku. Orang yang tidak mengaplikasikan nilai-nilai kebaikan, misalnya tidak jujur, kejam, rakus, dan perilaku jelek lainnya dikatakan orang yang berkarakter jelek, tetapi orang yang perilakunya sesuai dengan kaidah moral disebut dengan berkarakter mulia.

Franz Magnis Suseno (dalam Suyitno,2012), dalam acara Sarasehan Nasional Pengembangan Pendidikan Budaya dan Karakter Bangsa mengatakan bahwa pada era sekarang ini yang dibutuhkan bukan hanya generasi muda yang berkarakter kuat,tetapi juga benar, positif, dan konstruktif. Pernyataan itu disampaikan lebih dari 10 tahun yang lalu, artinya memang untuk saat ini pendidikan karakter menjadi suatu hal yang teramat penting untuk ditransformasikan ke anak didik. Lyons (dalam Putra, 2016) menjelaskan tentang generasi milenial, Dia menyatakan generasi $\mathrm{Y}$ dikenal dengan sebutan generasi millenial atau milenium. Ungkapan generasi Y mulai dipakai pada editorial koran besar Amerika Serikat pada Agustus 1993. Generasi ini banyak menggunakan teknologi komunikasi instan seperti email, SMS, instant messaging dan media sosial seperti facebook dan twitter, dengan kata lain generasi $\mathrm{Y}$ adalah generasi yang tumbuh pada era internet booming. 
Di era global seperti saat ini, seseorang memerlukan pengendali yang kuat agar ia mampu memilih dan memilah nilai-nilai yang banyak sekali ditawarkan kepadanya (Soedarsono, 1999; Djahiri, 2006). Oleh karena itu, agar seseorang tahan banting, maka bisa dilakukan melalui pendidikan, sebab jalan terbaik dalam membangun seseorang ialah pendidikan. Menurut Undang-Undang No. 20 Tahun 2003 Pendidikan adalah usaha sadar dan terencana untuk mewujudkan suasana belajar dan proses pembelajaran agar peserta didik secara aktif mengembangkan potensi dirinya untuk memiliki kekuatan spiritual keagamaan,

pengendalian diri, kepribadian, kecerdasan, akhlak mulia, serta ketrampilan yang diperlukan dirinya, masyarakat, bangsa dan negara. Sedangkan Jhon Dewey (2003: 69) menjelaskan bahwa -Pendidikan adalah

proses pembentukan kecakapan-kecakapan fundamental secara intelektual dan emosional kearah alam dan sesama manusiall. Dunia Pendidikan mempunyai peran dan tanggung jawab yang sangat penting untuk membawa perubahan dalam diri manusia, masyarakat dan lingkungan sosial. Namun dalam hal ini, tidak hanya pendidikan formal ataupun nonformal saja yang dibutuhkan dari generasimillennial, di butuhkan pula pendidikan karakter dalam membangun moral dan budipekerti pada generasi ini.

Karakter merupakan watak, tabiat, akhlak atau budi pekerti yang membedakan seseorang dari yang lain. Karakter dari suatu bangsa sangat dipengaruhi oleh kultur dari bangsa itu sendiri. Pembentukan karakter merupakan salah satu tujuan pendidikan nasional yang terdapat pada UU No. 20 tahun 2003 tentang sistem pendidikan nasional pasal 3, tujuan pendidikan nasional adalah mengembangkan potensi peserta didik agar menjadi manusia yang beriman dan bertakwa kepada Tuhan Yang Maha Esa, akhlak mulia, sehat, berilmu, cerdas, kreatif, mandiri dan menjadi warga

Negara yang demoktaris serta bertanggung jawab.

Megawangi (2007) menyebutkan bahwa Pendidikan Karakter sebagai solusi dalam menjawab permasalahan negeri ini.

Pendidikan karakter tidak hanya mendorong pembentukan perilaku positif anak, tetapi juga meningkatkan kualitas kognitifnya. Pengembangan karakter atau character building membutuhkan partisipasi dan sekaligus merupakan

tanggung jawab dari orangtua, masyarakat, dan pemerintah. Sebab dengan menjadi dewasa secara rohani dan

jasmani, seseorang menjadi berkepribadian yang bijaksana baik terhadap dirinya sendiri, keluarga, dan masyarakat (Illiyun, 2012)

Para pakar di Balitbang Pusat Kurikulum Kemendikbud berhasil menginvetarisasi 18 karakter yang harus menjadi acuan para pendidikan secara nasional (Satriwan, 2012). Nilai-nilai yang dikembangkan dalam pendidikan budaya dan karakter bangsa bersumber dari nilainilai Agama, Pancasila, Budaya dan Tujuan Pendidikan Nasional, yang kemudian diidentifikasi menjadi 18 karakter bangsa yaitu: religius, jujur, toleransi, disiplin, kerja keras, kreatif, mandiri, demokratis, rasa ingin tahu, semangat kebangsaan, cinta tanah air, 
menghargai prestasi, bersahabat/komunikatif, cinta damai, gemar membaca, peduli lingkungan, peduli sosial dan tanggung jawab (Satriwan, 2012).

Dalam pendidikan karakter

Muslich Masnur (2011:75) Lickona (1992) - menekankan pentingnya tiga komponen karakter yang baik (components of good character), yaitu moral knowing atau pengetahuan tentang moral, moral feeling atau perasaan tentang moral, dan moral action atau perbuatan morall. Hal ini diperlukan agar generasi millennial memahami, merasakan dan mengerjakan sekaligus nilai-nilai kebijakan. Pendidikan karakter adalah pendidikan budi pekerti plus, yaitu yang melibatkan aspek pengetahuan (cognitive), perasaan (feeling), dan tindakan (action).

Menurut FW Foerster terdapat 4 ciri dasar pendidikan karakter yaitu:

1. Pendidikan karakter nemenakankan setiap tindakan yang berpedoman terhadap nilai normatif. Dimana

diharapkan generasi dapat menghormati norma-norma yang ada dan dijadikannya berpedoman dalam bertingkahlaku dilingkungan masyarakat

2. Adanya korehensi atau membangun rasa percaya diri dan keberanian, dengan begitu seseorang akan menjadi pribadi yang teguh pendirian dan tidak mudah terombang ambing serta tidak takut terhadap resiko dalam situasi baru.

3. Adanya otonomi, yaitu seseorang menghayati dan mengamalkan atuan dari luar sampai menjadi nilai-nilai bagi pribadinya. Dengan begitu, seseorang mampu mengambil keputusan dengan mandiri tanpa dipengaruhi atau desakan dari orang lain.

4. Keteguhan dan kesetiaan. Keteguhan adalah daya tahan dalam mewujudkan apa yang dipandang baik dan kesetiaan merupakan dasar penghormatan atas komisten yang dipilih.

Pendidikan tidak hanya membentuk insan yang cerdas, namun juga berkarakter dan berkepribadian yang unggul dengan harapan agar generasi bangsa kelak dapat tumbuh dan berkembang dengan karakter yang berdasarkan nilai-nilai luhur bangsa dan agama. Dalam hal ini dapat disimpulkan peningkatan pendidikan karakter dapat dijadikan dasar dan perisai atau pengendali bagi generasi millennial dalam menghadapi perkembangan di era yang serba canggih atau era globalisasi. Sebagai generasi millennialperlu menyadari pula betapa pentingnya pendidikan karakter sebagai sarana pembentuk perilaku dan kepribadian dalam berprilaku di media internet dan dikehidupan sehari-hari. Dalam hal ini tidak hanya lingkungan sekolah yang menjadi pusat pembelajaran dari pendidikan karakter namun keluarga, lingkungan sekitar, masyarakat dan pemerintah pula ikut berperan aktif dalam mendukung hal tersebut, sehingga

terbentuklah generasi millennial yang berkarakter baik dan unggul yang berdasarkan nilai-nilai luhur bangsa dan agama. 


\section{DAFTAR PUSTAKA}

Azra, Azyumardi. Agama, Budaya, dan Pendidikan Karakter Bangsa. 2006

Elkind, David H. dan Sweet, Freddy. How to Do Character Education.

Artikel yang diterbitkan pada bulan September/Oktober 2004.

Kementerian Pendidikan Nasional, Badan penelitian dan pengembangan, Pusat kurikulum. 2011, Pengembangan pendidikan budaya dan karakter bangsa pedoman sekolah. Jakarta: Pusat Kurikulum

Kennedy,M. 1991, Some Surprising Finding on How Teachers Learn to Teach,Educational Leadership.

Lickona, Thomas, Educating for Character: How Our Schools Can Teach Respect and Responsibility. New York: Bantam Books, 1992. Lickona, Tom; Schaps, Eric, dan Lewis, Catherine. Eleven Principles of Effective Character Education. Character Education Partnership, 2007.

Megawangi, Ratna. Pengembangan

Program Pendidikan Karakter di
Sekolah: Pengalaman Sekolah

Karakter, 2010.

Parkay, Forrest W. dan Stanford,Beverly

H. 2011, Menjadi Seorang Guru, Jakarta

: PT Indeks.

Samani, Muchlas, Hariyanto. 2011.

Konsep dan Model Pendidikan Karakter.

Bandung Remaja

Rosdakarya.

Siswinarti, Putu. R. (2017). Pentingnya Pendidikan Karakter Untuk Membangun Bangsa Beradab.

Singaraja: Fakultas Ilmu Pendidikan Universitas Pendidikan Ganesha

Indonesia.https://www.researchgat e.net/publication/315100058.

Suyitno, Imam. (2012). Pengembangan Pendidikan Karakter dan Budaya Bangsa Berwawasan Kearifan Lokal. Jurnal Pendidikan Karakter, Tahun II Nomor 1, 1-13

Tilaar, HAR. 2002,Pendidikan Kebudayaan, dan Masyarakat Madani Indonesia, Bandung : PT Remaja Rosda Karya. 
